\title{
Respon pertumbuhan dan produksi tanaman sawi Pakcoy (Brassica chinensis L.) akibat pemberian berbagai jenis pupuk kandang
}

\author{
(The growth and production response of Pakcoy (Brassica chinensis L.) affectted by various \\ manure aplication)
}

\author{
R. Barokah, Sumarsono, dan A. Darmawati \\ Agroecotechnology, Faculty of Animal and Agricultural Sciences, Diponegoro University \\ Tembalang Campus, Semarang 50275 - Indonesia \\ CorrespondingE-mail: Rahmadun.okah@gmail.com
}

\begin{abstract}
The purpose of this research was to determine growth and production responses of Pakcoy (Brassica chinensis L.) due to the treatment of various type of manure and to determine types of manure which effective for the growth and production of Pakcoy. This Research was conducted at Experimental field and Laboratory of Plant Ecology and Production, Faculty of Animal and Agricultural Science, Diponegoro University from January to March 2017. This research used mono factor experiment in Completely Randomized Design arrangement. The treatment was variation of manure which were cow manure, goat manure, sheep manure, horse manure, and chicken manure, they would be compared with non treatment (no fertilizer) and $300 \mathrm{~kg} / \mathrm{ha}$ urea in four replications. The obtained data were processed statistically with analysis of variance (F test) and Duncan Multiple Range Test at 5\% level. The results showed that manure treatment with different types gave effect to the plant heigh, number of leaves, leaf area, and plant production. The best treatment was chicken manure treatment which produced average of plant height as $26.33 \mathrm{~cm}$, average number of leaves as 11 sheet, average of leaf area as $1033.30 \mathrm{~cm}^{2}$, and Spoon Mustard production as $2319.90 \mathrm{~g} / \mathrm{m}^{2}$.
\end{abstract}

Keywords: Organic Fertilizer, Manure, Pakcoy.

\begin{abstract}
ABSTRAK
Penelitian ini bertujuan untuk mengetahui respon pertumbuhan dan produksi sawi pakcoy akibat pemberian berbagai jenis pupuk kandang, serta mengetahui jenis pupuk kandang yang efektif untuk pertumbuhan dan produksi sawi pakcoy. Penelitian dilaksanakan di Lahan percobaan dan Laboratorium Ekologi dan Produksi Tanaman, Fakultas Peternakan dan Pertanian Universitas Diponegoro dari bulan Januari - Maret 2017. Penelitian ini menggunakan percobaan monofaktordengan rancangan acak lengkap.Perlakuan jenis pupuk kandang(sapi, kambing, domba, kuda, ayam) dibandingkan dengan tanpa pemupukan dan urea $300 \mathrm{~kg} / \mathrm{ha}$ dengan 4 kali ulangan. Data yang diperoleh diolah secara statistik dengan analisis ragam (uji F) dan dilanjutkan dengan uji jarak berganda duncan (UJGD) taraf 5\%. Hasil penelitian menunjukkan bahwa pemberian jenis pupuk kandang berpengaruh terhadap parameter tinggi tanaman, jumlah daun, luas daun dan produksi tanaman. Perlakuan terbaik diperoleh pada pupuk kandang ayam dengan rata-rata tinggi tanaman, jumlah daun, luas daun, dan produksi sawi pakcoy yaitu berturut 26,33 cm, 11 helai, $1033,30 \mathrm{~cm}^{2}$ dan $2319,90 \mathrm{~g} / \mathrm{m}^{2}$.
\end{abstract}

Kata Kunci: Pupuk Organik, Pupuk Kandang, Pakcoy

\section{PENDAHULUAN}

Sawi pakcoy (Brassica chinensis L.) merupakan tanaman dari keluarga Cruciferae yang sangat diminati karena mengandung protein, lemak, karbohidrat, Ca, P, Fe, vitamin A, B, C, E dan $\mathrm{K}$ yang sangat baik untuk kesehatan. Pakcoy juga memiliki nilai ekonomi yang tinggi. Selain 
itu produksi sawi pakcoy juga mengalami fluktuasi pada tahun 2012, 2013 dan 2014 yaitu 594,91; 635,70; dan 602,40 ton/tahun(Badan Pusat Statistik dan Direktorat Jenderal Hortikultura, 2015). Produksi sawi tersebut dapat disebabkan oleh kesuburan tanah, sehingga diperlukan budidaya yang baik untuk memperbaiki kesuburan tanah sekaligus meningkatkan produksi sawi pakcoy.

Kesuburan merupakan faktor yang sering menjadi permasalahan dalam budidaya tanaman di Indonesia. Penggunaan lahan untuk budidaya tanaman secara terus-menerus akan menurunkan kesuburan tanah baik fisik, kimia dan biologi. Upaya untuk mengatasi masalah tersebut dilakukan melalui pemupukan yang baik. Penggunaan pupuk organik bermanfaat karena mengandung semua unsur yang diperlukan tanah, selain itu dapat berperan sebagai perekat partikel tanah sehingga agregasi dan struktur tanah menjadi baik.Aplikasi pupuk organik dalam sistem pertanaman dapat meningkatkan kandungan bahan organik/C-organik dan kandungan $\mathrm{N}$ total dalam tanah (Zulkarnain dkk., 2013).Standar mutu kandungan bahan organik tanah yaitu memiliki $\mathrm{N} 0,21-0,50 \%$, C-organik 2,01-3,00\% dan rasio $\mathrm{C} / \mathrm{N}$ 11-15 (Sembiring, 2008). Selain itu penggunaan pupuk organik juga dapat mengurangi pencemaran, melaluidaur ulang hara dan pemanfaatan pupuk organik yang dapat dilakukan melalui sarana limbah pertanaman dan ternak, serta limbah lainnya. (Haryanto dkk., 2008).

Limbah peternakan/pertanian yang sering digunakan untuk pemupukan adalah pupuk kandang. Pupuk kandang dapat bermanfaat bagi tanaman karena mengandung unsur kompleks yang dibutuhkan tanaman seperti $\mathrm{N}, \mathrm{P}, \mathrm{K}, \mathrm{Ca}, \mathrm{Mg}$ dan S (Kusuma, 2012).Akan tetapi pukan tersebut memiliki $\mathrm{C} / \mathrm{N}$ ratio yang cukup tinggi yaitu antara 30 sampai $>40$. Berdasarkan ketentuan SNI: 197030-2004 bahwa $\mathrm{C} / \mathrm{N}$ ratio optimum dalam pupuk organik adalah 10-20\% (Suhesy dan Adriani, 2014).Oleh karena itu penggunaan pupuk organik memerlukan proses dekomposisi terlebih dahulu agar kandungan unsur haranya dapat diserap oleh tanaman (Pujisiswanto dan Pangaribuan, 2008).

Penelitian ini bertujuan untuk mengetahui respon pertumbuhan dan produksi sawi pakcoy akibat pemberian berbagai jenis pupuk kandang, serta mengetahui jenis pupuk kandang yang efektif untuk pertumbuhan dan produksi sawi pakcoy. Manfaat penelitian ini dapat memberi informasi pupuk kandang yang efektif untuk pertumbuhan dan produksi tanaman sawi pakcoy, serta memberi informasi mengenai budidaya tanaman sawi pakcoy secara organik.

\section{MATERI DAN METODE}

\section{Materi Penelitian}

Penelitian dilaksanakan di Lahan percobaan dan Laboratorium Ekologi dan Produksi Tanaman, Fakultas Peternakan dan Pertanian Universitas Diponegoro dari bulan Januari - Maret 2017. Materi yang digunakan meliputi benih pakcoy, pupuk kandang sapi, kambing, domba, kuda, ayam, pupuk urea $300 \mathrm{~kg} / \mathrm{ha}$ dan mulsa.

\section{Metode Penelitian}

Rancangan percobaan yang digunakan adalah percobaan monofaktor 7 perlakuan dan 4 ulangan dengan Rancangan Acak Lengkap (RAL). Perlakuan yang dicobakan adalah tanpa pemupukan (A0), pukan sapi (A1), pukan kambing (A2), pukan domba (A3), pukan kuda (A4), pukan ayam (A5), dan urea $300 \mathrm{~kg} / \mathrm{ha}$ (A6).

Penelitian dilaksanakan dengan menyiapkan lahan dengan cara mengolah dan membuat bedengan dengan lebar $1 \mathrm{x} 1,5 \mathrm{~m}^{2}$. Bedengan ditutup dengan mulsa serta dibuat jarak tanam 20 x $20 \mathrm{~cm}$. Penyemaian pakcoy dilakukan dua minggu sebelum tanam dengan menyemai benih dalam bak pembibitan. Bibit pakcoy siap dipindahkan saat berumur dua minggu atau memiliki rata-rata jumlah daun 3-4 helai. Pemupukan dilakukan satu minggu sebelum tanam dengan mengaplikasikan pupuk pada masing-masing lubang tanam. Dosis pupuk yang digunakan yaitu $138 \mathrm{~N} / \mathrm{ha}$ yang disesuaikan dengan masing-masing kandungan pupuk berdasarkan analisis laboratorium. Pemeliharaan tanaman meliputi penyiraman, penyulaman, penegendalian gulma, serta pengendalian hama dan penyakit.

Parameter yang diamati yaitu 1) tinggi tanaman, 2) jumlah daun, 3) luas daun dan indeks 
luas daun, 4) produksi segar tajuk, 5) komponen bahan kering, 6) serapan $\mathrm{N}$ tanaman. Tinggi tanaman dan jumlah daun diamati setiap satu minggu sekali dimulai dari minggu pertama setelah tanam. Luas daun, produksi segar tajuk, komponen bahan kering, dan serapan $\mathrm{N}$ tanaman diamati pada saat panen yaitu 4 minggu setelah tanam.

Data yang diperoleh diolah secara statistik dengan analisis ragam (uji F). Apabila terdapat pengaruh perlakuan yang nyata $(p<0,05)$ maka dilanjutkan dengan uji jarak berganda Duncan (UJGD) taraf 5\%.

\section{HASIL DAN PEMBAHASAN}

\section{Pertumbuhan Tanaman}

Hasil analisis ragam menunjukkan bahwa pemberian jenis pupuk kandang berpengaruh nyata $(p<0,05)$ terhadap pertumbuhan dan produksi tanaman sawi pakcoy pada semua parameter. Hasil penelitiandisajikan pada Tabel 1.

Pertumbuhan tinggi tanaman, jumlah daun,dan luas daun tanaman tertinggi terdapat pada perlakuan pupuk kandang ayam yaitu berturut-turut 26,73 cm, 10,90 helai, dan 1033,30 $\mathrm{cm}$ (Tabel 1), hasil terendah terdapat pada perlakuan tanpa pemupukan dan urea $300 \mathrm{~kg} / \mathrm{ha}$ yaitu berturut-turut 15,28 cm, 5,96 helai, dan 1033,30 cm (Tabel 1).

\section{Tinggi Tanaman}

Tabel 1 menunjukkan bahwa tinggi tanaman perlakuan pupuk kandang sapi, kambing, domba, kuda, dan ayam berbeda nyata $(p<0,05)$ lebih tinggi dibandingkan dengan perlakuan tanpa pemupukan dan urea $300 \mathrm{~kg} / \mathrm{ha}$.

Pemberian pupuk kandang memiliki perumbuhan tinggi yang lebih baik dibandingkan perlakuan tanpa pupuk dan pupuk urea (Tabel 1). Pupuk kandang efektif untuk meningkatkan kesuburan tanah, sehingga tanah dapat memenuhi kebutuhan unsur hara bagi tanaman. Bahan organik dalam pupuk kandang dapat membantu dalam proses penyerapan air dan sinar matahari bagi tanah, sehingga tanah akan menjadi subur (Panata, 2010). Perlakuan pupuk kandang ayam menghasilkan tinggi tanaman tertinggi dikarenakan memiliki kadar $\mathrm{N}$ yang tinggi serta rasio $\mathrm{C} / \mathrm{N}$ yang lebih rendah dibandingkan dengan pupuk yang lain, sehingga unsur $\mathrm{N}$ dapat diserap lebih baik oleh tanaman. Pupuk kandang ayam yang sudah terdekomposisi memiliki kandungan $\mathrm{N}$ yang tinggi sertarasio $\mathrm{C} / \mathrm{N}$ yang baik yaitu antara 10-20 (Surya dan suyono 2013). Sedangkan perlakuan tanpa pemupukan dan urea $300 \mathrm{~kg} / \mathrm{ha}$ memiliki hasil terendah dikarenakan tanaman mengalami kekurangan unsur hara nitrogen. Kekurangan unsur $\mathrm{N}$ dapat menghambat pertumbuhan tanaman karena $\mathrm{N}$ berfungsi untuk meningkatkan pertumbuhan tinggi tanaman

Tabel 1. Pertumbuhan Tanaman Sawi Pakcoy

\begin{tabular}{lccc}
\hline \hline Perlakuan & \multicolumn{3}{c}{ Parameter } \\
\cline { 2 - 4 } & Tinggi Tanaman & Jumlah Daun & Luas Daun \\
\hline & $\mathrm{cm}$ & helai & $\mathrm{cm}^{2}$ \\
Tanpa Pemupukan (A0) & $15,28^{\mathrm{c}}$ & $5,96^{\mathrm{c}}$ & $189,30^{\mathrm{c}}$ \\
Pupuk Kandang Sapi (A1) & $23,93^{\mathrm{ab}}$ & $8,75^{\mathrm{b}}$ & $680,30^{\mathrm{ab}}$ \\
Pupuk Kandang Kambing (A2) & $24,10^{\mathrm{ab}}$ & $10,05^{\mathrm{ab}}$ & $758,50^{\mathrm{ab}}$ \\
Pupuk Kandang Domba (A3) & $22,70^{\mathrm{b}}$ & $9,70^{\mathrm{ab}}$ & $598,30^{\mathrm{b}}$ \\
Pupuk Kandang Kuda (A4) & $24,40^{\mathrm{ab}}$ & $10,60^{\mathrm{a}}$ & $744,80^{\mathrm{ab}}$ \\
Pupuk Kandang Ayam (A5) & $26,73^{\mathrm{a}}$ & $10,90^{\mathrm{a}}$ & $1033,30^{\mathrm{a}}$ \\
Urea 300 kg (A6) & $16,33^{\mathrm{c}}$ & $6,65^{\mathrm{c}}$ & $183,50^{\mathrm{c}}$ \\
\hline
\end{tabular}

Nilai yang diikuti superskrip yang sama didalam kolom yang sama menunjukkan hasil tidak berbeda nyata $(\mathrm{p}>0,05)$ berdasarkan UJGD. 
(Nurshanti, 2009).

\section{Jumlah daun}

Tabel 1 menunjukkan bahwa jumlah daun perlakuan pupuk kandang sapi, kambing, domba, kuda, dan ayam berbeda nyata $(\mathrm{p}<0,05)$ lebih tinggi dibandingkan dengan perlakuan tanpa pemupukan dan urea $300 \mathrm{~kg} / \mathrm{ha}$.

Pemberian pupuk kandang memiliki perumbuhan jumlah daun yang lebih baik dibandingkan perlakuan tanpa pupuk dan pupuk urea (Tabel 1). Pemberian pupuk kandang lebih efektif dalam meningkatkan pertumbuhan tanaman karena pupuk kandang memiliki kandungan hara yang lengkap dalam memenuhi kebutuhan tanaman. Pupuk kandang yang berasal dari kotoran hewan mengandung unsur hara makro seperti nitrogen $(\mathrm{N})$, posfor $(\mathrm{P})$, kalium $(\mathrm{K})$, kalsium $(\mathrm{Ca})$, magnesium $(\mathrm{Mg})$ dan belerang (S), sehingga dapat memenuhi kebutuhan unsur hara tanaman sawi pakcoy (Kusuma, 2012). Pemberian pupuk kandang ayam menghasilkan jumlah daun terbanyak, hal ini dikarenakan pupuk kandang ayam mengandung nitogen yang tinggi dalam memenuhi kebutuhan nutrisi tanaman, serta memiliki rasio $\mathrm{C} / \mathrm{N}$ yang rendah sehingga nitrogen mudah diserap oleh tanaman. Pertumbuhan tanaman memerlukan suplai nitrogen yang cukup dan berimbang dengan unsur hara lainnya, selain itu unsur hara yang tersedia juga harus sesuai agar dapat diserap oleh tanaman (Ningsih 2013).

\section{Luas daun}

Tabel 1 menunjukkan bahwa luas daun perlakuan pupuk kandang sapi, kambing, domba, kuda, dan ayam berbeda nyata $(p<0,05)$ lebih tinggi dibandingkan dengan perlakuan tanpa pemupukan dan urea $300 \mathrm{~kg} / \mathrm{ha}$. Luas daun tertinggi terdapat pada perlakuan pupuk kandang ayam (A5) yaitu $1033,30 \mathrm{~cm}$ sedangkan hasil terendah terdapat pada perlakuan urea $300 \mathrm{~kg} / \mathrm{ha}$ yaitu $183,50 \mathrm{~cm}$ (Tabel 1). Seiring dengan tinggi tanaman dan jumlah daun semakin tinggi pertumbuhan tanaman semakin tinggi pula luas daunnya. Pemberian pupuk kandang juga efektif meningkatkan luas daun tanaman, hal ini menunjukkan bahwa tanaman sudah berkucukupan kebutuhan haranya sehingga tanaman membentuk organ tubuh yang lebih tinggi/banyak termasuk organ sebagai tempat berlangsungnya proses fotosintesis (Nugroho dkk., 2013).Erawan (2013) menambahkan bahwa meningkatnya luas daun tanaman disebabkan karena tersedianya unsur nitrogen yang dapat diserap oleh tanaman, sehingga pertumbuhan tanaman seperti luas daun juga meningkat. Pemberian pupuk kandang ayam memiliki hasil tertinggi yang menunjukkan bahwa pupuk kandang ayam dapat menyediakan unsur hara lebih baik dibandingkan pupuk kandang lainnya. Unsur nitrogen yang tersedia dalam jumlah cukup dapat meningkatkan jumlah daun dan laju fotosintesis tanaman, sehingga daun dapat menghasilkan fotosintat dan energi yang lebih tinggi untuk pertumbuhan dan produksinya (Sari dkk., 2016).

\section{Produksi Tanaman}

Hasil analisis ragam menunjukkan bahwa pemberian jenis pupuk kandang berpengaruh nyata $(p<0,05)$ terhadap pertumbuhan dan produksi tanaman sawi pakcoy pada semua parameter.Hasil penelitian disajikan pada Tabel 2.

Produksi tanaman tertinggi terdapat pada perlakuan pupuk kandang ayam (A5) yaitu $2319,90 \mathrm{~g} / \mathrm{m}^{2}$, sedangkan hasil terendah terdapat pada perlakuan tanpa pemupukan yaitu 283,50 $\mathrm{g} / \mathrm{m}^{2}$. Pemberian pupuk kandang menghasilkan produksi tanamannyata $(\mathrm{p}<0,05)$ lebih tinggi dibandingkan perlakuan tanpa pupuk dan pupuk urea. Pupuk kandang dapat meningkatkan kandungan unsur hara dan daya ikat air tanah, sehingga akar tanaman dapat lebih mudah menyerap nutrisi dalam meningkatkan produksi tanaman. Pemberian pupuk kandang dapat meningkatkan bahan organik dalam tanah sehingga pertumbuhan dan produksi tanaman lebih optimal (Azizah dkk., 2016). Pupuk kandang ayam menghasilkan produksi tertinggi dibandingkan dengan perlakuan lain, hal ini dikarenakan pupuk kandang ayam memiliki rasio $\mathrm{C} / \mathrm{N}$ yang rendah dibandingkan pupuk kandang lain sehingga unsur $\mathrm{N}$ lebih mudah diserap tanaman. Pupuk kandang ayam mengandung unsur hara yang lengkap bagi pertumbuhan tanaman, meningkatkan kesuburan tanah, serta meningkatkan daya tahan dan daya serap tanah 
Tabel 2. Produksi Tanaman Sawi Pakcoy.

\begin{tabular}{lc}
\hline Perlakuan & Produksi \\
\hline & $\mathrm{g} / \mathrm{m}^{2}$ \\
Tanpa Pemupukan (A0) & $283,50^{\mathrm{c}}$ \\
Pupuk Kandang Sapi (A1) & $1297,30^{\mathrm{b}}$ \\
Pupuk Kandang Kambing (A2) & $1535,90^{\mathrm{ab}}$ \\
Pupuk Kandang Domba (A3) & $1176,00^{\mathrm{b}}$ \\
Pupuk Kandang Kuda (A4) & $1587,20^{\mathrm{ab}}$ \\
Pupuk Kandang Ayam (A5) & $2319,90^{\mathrm{a}}$ \\
Urea 300 kg (A6) & $290,50^{\mathrm{c}}$ \\
\hline
\end{tabular}

Nilai yang diikuti superskrip yang sama didalam kolom yang sama menunjukkan hasil tidak berbeda nyata $(\mathrm{p}>0,05)$ berdasarkan UJGD.

terhadap air sehingga akar dapat lebih mudah menyerap unsur hara (Pinem dkk., 2015).

\section{KESIMPULAN}

Hasil penelitian menunjukkan bahwa pemberian jenis pupuk kandang menghasilkan pertumbuhan dan produksi tanaman sawi lebih tinggi dibandingkan perlakuan tanpa pupuk dan pupuk urea. Pupuk kandang ayam merupakan jenis pupuk kandang yang paling efektif dalam meningkatkan pertumbuhan dan produksi tanaman sawi pakcoy.

\section{DAFTAR PUSTAKA}

Azizah, N., G. Haryono dan Tujiyanta. 2016. Respon macam pupuk organik dan macam mulsa terhadap hasil tanaman sawi caisin (Brassica juncea L.) var. tosakan. Vigor Jurnal Ilmu Pertanian Tropika dan Subtropika. 1 (1): 44-51.

Badan Pusat Statistik dan Direktorat Jenderal Hortikultura. 2015. Statistik Produksi Hortikultura Tahun 2014. Badan Pusat Statistik dan Direktorat Jenderal Hortikultura, Kementrian Pertanian.

Erawan, D., W.O. Yani, dan A. Bahrun. 2013. Pertumbuhan dan hasil tanaman sawi (Brassica juncea L.) pada berbagai dosis pupuk urea. J. Agroteknos. 3 (1): 19-25.

Haryanto, K. Idris, R. I. Kawalusan, dan E. L.
Sisworo. 2008. Pengaruh pupuk fosfat alam pada tanah masam terhadap pertumbuhan jagung serta serapan N-Za dan N-Urea. J. Ilmiah Aplikasi Isotop dan Radiasi. 4 (2): 130-142.

Kusuma, M. E. 2012. Pengaruh beberapa jenis pupuk kandang terhadap kualitas bokashi. J. Ilmu. Hewani. Tropika. 1 (2) : 41-46.

Ningsih, S.S. 2013. Pengaruh pemberian pupuk kandang ayam dan pupuk N (ZA) terhadap pertumbuhan serta produksi tanaman sawi (Brassica juncea L.). J. Penelitian Pertanian BERNAS. 9 (1): 1-6.

Nugroho, Y.A., Y. Sugito, L. Agustina, dan Soemarno. 2013. Kajian penambahan dosis beberapa pupuk hijau dan pengaruhnya terhadap pertumbuhan tanaman selada (Lactuca sativa L.). J. Exp. Life. Sci. 3 (2): 45-53.

Nurshanti, D.F. 2009. Pengaruh pemberian pupuk organik terhadap pertumbuhan dan hasil tanaman caisin (Brassica juncea L.). J. Agronobis. 1 (1): 89-98.

Parnata, A.S. 2010. Meningkatkan Hasil Panen dengan Pupuk Organik. AgroMedia Pustaka, Jakarta.

Pinem, D.Y.F., T, Irmansyah dan F.E.T. Sitepu. 2015. Respon pertumbuhan dan produksi 
brokoli terhadap pemberian pupuk kandang ayam dan jamur pelarut fosfat. J. Online Agroekoteknologi. 3 (1): 198-205.

Pujisiswanto, H. dan D. Pangaribuan. 2008. Pengaruh dosis kompos pupuk kandang sapi terhadap pertumbuhan dan produksi buah tomat. Prosiding Seminar Nasional Sains dan Teknologi-II. Universitas Lampung, 17-18 November 2008. Hal. 11-19.

Sari, R.M.P., M.D. Maghfoer dan Koesriharti. 2016. Pengaruh frekuensi penyiraman dan dosis pupuk kandang ayam terhadap pertumbuhan dan hasil tanaman pakchoy (Brassica rapa L. var. chinensis). J. Produksi Tanaman. 4 (5): 342-351.

Sembiring, S. 2008. Sifat kimia dan fisik tanah pada areal bekas tambang bauksit di Pulau Bintan, Riau. Info Hutan 5 (2): 123-134.
Suhesy, S. dan Adriani. 2011. Pengaruh probiotik dan trichorderma terhadap hara pupuk kandang yang berasal dari feses sapi dan kambing. J. Ilmiah Ilmu-ilmu Peternakan. 17 (2), 45-53.

Surya, R.E. dan Suyono. 2013. Pengaruh pengomposan terhadap rasio $\mathrm{C} / \mathrm{N}$ kotoran ayam dan kadar hara NPK tersedia serta kapasitas tukar kation tanah. UNESA Journal of Chemistry. 2 (1): 137-144

Zulkarnain, M., Prasetya, B., dan Soemarno. 2013. Pengaruh kompos, pupuk kandang, dan custom-bio terhadap sifat tanah, pertumbuhan dan hasil tebu (Saccharum officinarum L.) pada entisol di kebun Ngrakah-Pawon Kediri. Indonesian Green Technologi Journal. 2 (1) : 45-52. 